\begin{tabular}{|l|l|l||}
\hline \multicolumn{2}{|c|}{ PublisherInfo } \\
\hline \hline PublisherName & $:$ & BioMed Central \\
\hline \hline PublisherLocation & $:$ & London \\
\hline \hline PublisherImprintName & $:$ & BioMed Central \\
\hline \hline
\end{tabular}

\title{
IL-12: a candidate autoimmunity susceptibility gene
}

\begin{tabular}{||l|l|l||}
\hline \multicolumn{2}{|c|}{ ArticleInfo } \\
\hline \hline ArticleID & $:$ & 87 \\
\hline \hline ArticleDOI & $:$ & $10.1186 /$ ar-2001-68181 \\
\hline \hline ArticleCitationID & $:$ & 68181 \\
\hline \hline ArticleSequenceNumber & $:$ & 44 \\
\hline \hline ArticleCategory & $:$ & Paper Report \\
\hline \hline ArticleFirstPage & $:$ & 1 \\
\hline \hline ArticleLastPage & $:$ & 3 \\
\hline \hline & & RegistrationDate $: 2001-7-26$ \\
ArticleHistory & $:$ & Received \\
& Accepted $2001-3-15$ \\
& $:$ 2001-7-26 \\
\hline \hline ArticleCopyright & $:$ & Biomed Central Ltd2001 \\
\hline \hline ArticleGrants & $:$ & \\
\hline \hline
\end{tabular}




\begin{tabular}{|l|l|l|l|}
\hline ArticleContext & $:$ & 130753311 \\
\hline
\end{tabular}

Anne Barton, ${ }^{\text {Aff1 }}$

Aff1 University of Manchester, UK

Keywords

Association, autoimmunity, diabetes, genetic, IL-12, linkage

\section{Context}

Type 1 diabetes (insulin-dependent diabetes mellitus [IDDM]) is an autoimmune disease with both genetic and environmental susceptibility components. The major susceptibility component is the human leukocyte antigen complex (HLA) but an unknown number of, as yet, unidentified genes are also required to mediate susceptibility. The non-obese diabetic (NOD) mouse spontaneously develops IDDM and differs from non-susceptible strains in the IL12B gene. Which encodes the p40 subunit of the interleukin (IL)-12. IL-12 promotes differentiation of T cells to the Th1 subset, and it is this group of cells that are thought to be involved in cell-mediated immunity. In NOD mice, Th1 cells mediate progression to IDDM and administration of IL-12 to prediabetic NOD mice accelerates the onset of diabetes.

\section{Significant findings}

The IL12B gene maps to 5q33-34. Linkage to this region was demonstrated in 249 IDDM affected sibling pair (ASP) families (maximum multipoint LOD score 1.7). The evidence for linkage was increased in families where the affected siblings shared identical alleles at the HLA locus (LOD score 2.3), suggesting that susceptibility in some families is mediated by an interaction between a gene in the 5q33-34 region and HLA. Association with $I L 12 B$ was replicated in an independent cohort of 238 IDDM ASP families with preferential transmission of allele 1 (the common allele) of the 3' UTR polymorphism to affected offspring. Expression of IL12B protein was significantly reduced in EBVtransformed cell lines of the $2 / 2$ genotype compared with the $1 / 1$ genotype, suggesting that this polymorphism could have a functional role. 


\section{Comments}

Linkage and association with the IL12B gene have been identified in IDDM families. The IL12B gene was investigated in these families because polymorphism in the equivalent gene in mice is associated with IDDM. A functional role for an IL12B 3' UTR polymorphism has been suggested by the finding that the presence of two copies of the rare allele is associated with a significant reduction in IL-12B protein expression. An increased level of IL-12 promotes differention to Th1 cells and may aggravate autoimmune destruction of ? cells, thereby causing IDDM. As the IL12B gene is also a candidate susceptibility gene for other T-cell-mediated autoimmune diseases, it would seem appropriate to test for association with such diseases.

\section{Methods}

Linkage analysis: MapMaker/Sibs; Association analysis: transmission disequilibrium test, transmission to sib-pair test; Gene expression: northern blot

\section{Additional information}

\section{References}

1. Morahan G, Huang D, Ymer SI, Cancilla MR, Stephen K, Dabadghao P, Werther G, Tait BD, Harrison LC, Colman PG: Linkage disequilibrium of a type 1 diabetes susceptibility locus with a regulatory IL12B allele. Nat Genet. 2001, 27: 218-221.

This PDF file was created after publication. 